\title{
Discernment from the Youth Standpoint upon Young Leaderships in Politics: A Case Study in Malaysia
}

Bryan Nathen, Syed Agil Bin Shekh Alsagoff, Saiful Nujaimi Abdul Rahman, Siti Shazwani Ahmad Suhaimi, Nur Shuhamin Nazuri

To Link this Article: http://dx.doi.org/10.6007/IJARBSS/v11-i11/11538～DOI:10.6007/IJARBSS/v11-i11/11538

Received: 14 September 2021, Revised: 20 October 2021, Accepted: 30 October 2021

Published Online: 24 November 2021

In-Text Citation: (Nathen et al., 2021)

To Cite this Article: Nathen, B., Alsagoff, S. A. B. S., Rahman, S. N. A., Suhaimi, S. S. A., \& Nazuri, N. S. (2021). Discernment from the Youth Standpoint upon Young Leaderships in Politics: A Case Study in Malaysia. International Journal of Academic Research in Business and Social Sciences, 11(11), 2471-2498.

Copyright: (c) 2021 The Author(s)

Published by Human Resource Management Academic Research Society (www.hrmars.com)

This article is published under the Creative Commons Attribution (CC BY 4.0) license. Anyone may reproduce, distribute, translate and create derivative works of this article (for both commercial and non0-commercial purposes), subject to full attribution to the original publication and authors. The full terms of this license may be seen

at: http://creativecommons.org/licences/by/4.0/legalcode

Vol. 11, No. 11, 2021, Pg. $2471-2498$

Full Terms \& Conditions of access and use can be found at http://hrmars.com/index.php/pages/detail/publication-ethics 


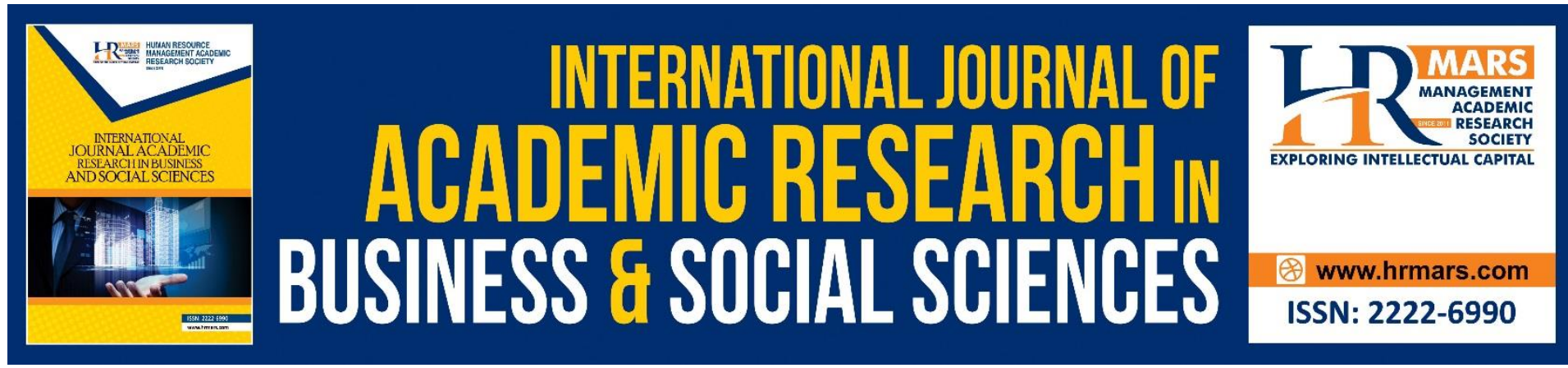

\title{
Discernment from the Youth Standpoint upon Young Leaderships in Politics: A Case Study in Malaysia
}

\author{
Bryan Nathena, Syed Agil Bin Shekh Alsagoffa, Saiful Nujaimi \\ Abdul Rahmana , Siti Shazwani Ahmad Suhaimi ${ }^{b}$, Nur Shuhamin \\ Nazurib \\ aDepartment of Communication, Faculty Of Modern Languages and Communication, \\ Universiti Putra Malaysia, Serdang, Malaysia Universiti Putra Malaysia, Serdang, Malaysia, \\ ${ }^{b}$ Department of Social and Development Sciences, Universiti Putra Malaysia, Serdang, \\ Malaysia Universiti Putra Malaysia, Serdang, Malaysia \\ Corresponding Author: s_agil@upm.edu.my
}

\begin{abstract}
In the earlier days of politics, youths were apathetic in the field of politics as the culture of politics was more suited to the older generation. This is because the older generation had more opportunities to cast partisan votes and developed stronger affiliations to the party for which they voted. However, with the ability to access information and engage online for everyone, this heterogeneous culture has given Malaysian youths a new and tangible existence in the scene of politics. Therefore, the purposes of this study is to explore the issues faced by youths in politics, how can aspiring politicians communicate effectively with youths today and to understand how does political communication work in youth circles. The study interviewed fifteen respondents, which all of them were university students between the ages of 18 and 35 . The data collection strategy was an in-depth interview followed by a semistructured interview protocol. Through the thematic analysis, this study found that there are still barriers surrounding politics, which are age, experience, and general perception between old and new politicians, including education, which seems to be a recurring topic. Furthermore, this research also spotted out that females do not have a significant share of voice in politics. This has concluded that the youth political environment remains an undeveloped area in Malaysia.
\end{abstract}

Keywords: Youth, Political Participation, Development, Political Behaviour, Information, Communication

\section{Background}

In recent developments of the political situations in Malaysia, it is disturbing to discover that not enough research has been dedicated to this particular area. Though it is understandable that in a field such as politics, a vast amount of experience in statesmanship and economic know-how is needed to lead countries. In the earlier days of politics, youths 
were apathetic in the field of politics as the culture of politics was more suited to the older generation. This is because the older generation had more chances to cast partisan votes, and more firmly form their identities with the party they were voting for (Niemi \& Jennings, 1991; Keith et al., 1992). The youths in the 1990s did not have the psychological connections with politics because they focused on other short-term issues such as dealing with adulthood, employment, and relationships (Bennett, 1997; Galston \& Galston, 2002).

However, with the ability to access information and engage online for everyone, this heterogenous culture has given youths a new and tangible existence in the scene of politics (Thorson, 2014). This form of engaging with information has also given youths various forms of political participation, allowing youths many methods to debate politics and engage with the politicians themselves in policy making (Cammaerts, Bruter, Banaji, Harrison, \& Anstead, 2014; Theocharis \& Van Deth, 2018). They note that previously offline acts can now be taken online with lower costs, which gives the public advantage in pursuing politics through so many mediums such as social media and discussion forums. The youth demand broader horizons, a foresight in creating a flourishing job market, a stronger economy, and progressive policies. Thus, the youth have begun to give outstanding support to the young leaders who endeavor to represent them.

This has pushed organizations to have to change the way they interact with new audiences as the next generations continue to grow into competent decision-makers. This is proven by a follow-up study by Etgar and Tamir (2020), who updated a study on the rational decision-making capacity of millennial students compared to the 1990s. From what was studied, shows that millennials are more rational when offered new information, with an increasing likelihood that they will embrace this new information to make alternative decisions rather than maintain the safe choice that is initially offered. Hence, it is in the wisdom that investments should be done to actively involve the participation of youths in politics. Ahmad and Sheikh (2020) reinforces this by emphasizing the importance to mobilize opinions among youths through both offline and online mediums as the circumstances of the country are quickly determined by youth sentiments. Thus, molding their strategies to focus on youths as one of the primary audiences. Using youths as the representation of a party in communication serves to galvanize youths to support a party's cause. The party encourages youths to be politically active through the party's ideals.

As such, political parties take this development seriously and tap younger members of their parties to take charge in policy making. Many political parties, especially the opposition sides, have established their own youth organizations (Nikitin, Nikitina \& Filimonov, 2019). In other parts of the world, we can see the effectiveness of fielding youths as political leaders. Young leaders such as American Member of Congress Alexandria Ocasio-Cortez and Finland Prime Minister, Sanna Marin have begun taking to the world stage with their outspoken leadership on progressive change. In Malaysia, we see institutions such as the Institute for Democracy and Economic Affairs, the Malaysian National Youth Association, and the Youth Parliament of Malaysia bringing forth ideas of youthful politics. There is also Youth and Sports Minister, Syed Saddiq, who arguably sparked a more aggressive youth movement in Malaysia through his appointment into the cabinet. However, parties may sometimes be negligent in developing the youth wings of their parties, which leads to a loss of interest on the part of youths towards politics (Elishev, 2010; Mardani \& Fallah, 2018). 
In certain constituencies, we have begun to see voters putting trust in youthful and new faces to represent them in parliament. It is young leaders such as these who are beginning to define the qualities needed to fulfill the criteria of entering politics at a young age. This influence has also moved other youths to push more loudly for reforms, with ad-hoc young leaders on youth reforms demonstrating their need for change through any channel they can find. Such a spur into the youth movement requires further understanding of how youths view young leadership. This study leads with an idea of exploring the understanding of youths towards youth leadership and what kind of impact this concept brings to our current world of politics. We will begin to understand the motivations behind youths choosing a young leader among themselves to create a change and the complexities in determining what demographic is best to lead the country.

Samsi, Rahman and Samsu (2014) noted that Malaysian youths were less involved in elections before the $14^{\text {th }}$ Malaysian General Election. This was a concerning trend as his study highlighted that in 2014, among the 3.7 million eligible youths in Malaysia, at least $60 \%$ were not involved in the election process. The amount of non-participation from this demographic showed the low levels of engagement between youths and politics, as they stated work and studies as their primary reasons for not participating in elections. Participation was low during that time despite the significant coverage from the media and influence from social environments. However, coverage from the media combined with social environments would add up to clutter the understanding of youths. The constant back and forth conversation between rival political parties contribute to the confusing messages that discourage youths from making efforts to understand what is going on.

The communications from agents in politics, such as non-government organizations, youth syndicates, opposition parties, and the ruling parties have experienced problems of distrust between them and the youths. Youth opinion leaders are able to rely on their own social networks to build political influence as well, due to the availability of many informational and communication tools (Yom, Lynch \& al-Khatib, 2019). The new age of communication which involves digital media has caused changes in how political opinions are formed, youths are breaking away from the conventional strategies used by political parties to influence the youths (Xenos, Vromen \& Loader, 2014). Levin (2007) also highlighted that youths have evolved to have a distinct set of political interests and interactions. Thus, interacting with youths in political discourse has changed significantly over the years and is harder to pinpoint.

There are difficulties exclusive to each demographic. With youths, the study hopes to identify the main problems of appealing to this dynamic demographic, whose wants and needs shift according to many factors such as social media and the economy (Schulz, 2014). In this dynamism, politicians engage with youths in forums and speaking engagements as a primary way of penetrating this demographic. It is noted that awareness and knowledge of the general election processes were not a problem among the youth. The effort to inform is not a problem as youths are constantly updated about politics. More than that, understanding the beliefs and values of the audience a politician is trying to appeal to is often the way to gain public favor (Boyman, 2017). 
Information and communication technology are a need for political parties to persuade and mobilize their supporters to give their vote (Stanyer, 2005). Within communication, political marketing is a term that is regularly practiced in modern politics, consulting voters on policy development and giving them value as stakeholders foster a sense of political ownership (Dean \& Croft, 2001). In election phases, this concept is observable as candidates engage with communities in forums and talks to receive feedback and build voter confidence. Communication practices are embedded in political engagements as much as it is necessary for the corporations, treat political communication efforts as part of a corporate social responsibility to gain favors from stakeholders (McNair, 2017). Youths have become a significant demographic for any country, they are a vocal segment that processes more information quickly due to the availability of technology. This makes constant communication a vital element to a successful political engagement.In the past, citizens were only passive recipients of the information. There was no room where criticism or feedback can be made on important topics. This effectively established a hierarchy of information that trickles down to the consumers (Leong, 2015). The 21st century came with new technology that equalized the field of communication, where everyone is able to contribute to the marketplace of ideas. The youths are one of the demographics who found power in this change. This eliminated the hierarchy structure, making the youth demographics a significant element in a successful political campaign (Gerodimos, 2010).

While the media has the power to frame information, it is up to the agents of change to create and promote how information can be framed in order to generate maximum opinion benefits (Nelson \& Oxley, 1999). Welfare can be framed as "encouraging dependency", which can promote discrimination towards those receiving welfare packages. Disregarding a segmentation to satisfy another, without proper communication, encourages negative opinions which will reflect badly on a political establishment (Nelson \& Kinder, 1996). This can be observed in the political environment in multicultural Malaysia, where political parties have the problem of communicating too much with a segmentation while paying less attention to another. Communication plays a part here in mitigating reputational damage to a political party and its candidates, particularly during the election phase. Therefore, the purposes of this study is to explore the issues faced by youths in politics, how can aspiring politicians communicate effectively with youths today and to understand how does political communication work in youth circles.

\section{Literature Review}

Communication in politics focuses on swaying public opinion based on combined elements from mass communication, political communication, and mass media communication. The goal of focusing on communication in politics is to study how communication can be used to create changes in political behavior such as voting (Lippman, 1922; Filatova, Golubev, \& Ulianovskii, 2016; Han, \& Xu, 2020). Lippman founded the documents that formed the first ideas of setting agendas by studying early examples of propaganda and its applications in garnering support towards a political party's causes. Another aspect studied in communication is how marketing from business can be applied in politics as well. However, the main difference between business and politics is that marketing is used to earn profit in business, whereas in politics, it is used to ensure the successful operation of democracy (Newman \& Perloff, 2004; Newman, Perloff \& Kaid, 2004). Hence, the term of communication in politics includes a variety of functions that functions similarly 
to business as well. How marketing can be used to encourage buyers, can be used to generate support for a political organization as well, in other words, it is coined as political marketing (Newman \& Perloff, 2004).

Within politics, contain social movements that define multiple audiences, political communication requires that multiple audiences be engaged at the same time with equal transparency in information (Lasswell, 1948). Each of these audiences has different agendas that communication strategies must address across the board. For a political organization to communicate effectively with different audiences, it must acknowledge the issues faced by different parties (Earl \& Beyer, 2014). Failing to do so can lose the favor of particular audiences, which will translate to the percentage of votes lost in a potential election. The mass media also has an effect on how political communication has changed since Mazzoleni and Schulz's (1999) initial research, which questioned the effects that political communication and mass media, has on democracy. They noted that a "new order" of how things will function is taking shape and replacing the old systems in the $20^{\text {th }}$ century. Since then, the proliferation of digital, social, and mobile media has led to strong ties between the media environment and political communication (Vowe \& Henn, 2016). The decline of traditional news media is given way to new powers from digital or online media flourish (Mitchell, Gottfried, Barthel, \& Shearer, 2016), this change has accelerated how changes in political organization and how it interacts with media environments (Blumler, 2016).

Until recently, the mass media was considered to be the main factor in political communication, it is how information researches the masses to help them make an informed decision (Kovach \& Rosenstiel, 2007). Through this change, political information can now be fed to influence voters more directly, which scholars have argued to raise tensions and concerns even further due to more unregulated discussions cropping up all over online media (Van Aelst et al., 2017). This high choice media environment allows people to easily opt-out of news and only consume content of their choice, making publics who consume information biased. News avoiders are also a major concern of political communication in today's environment, as news has a weaker effect on the public due to the dilution of media (Blekesaune, Elvestad, \& Aalberg, 2012; Strömbäck, Djerf-Pierre, \& Shehata, 2013). It is still largely an open question of how much information people consume and are influenced by in digital media (Hindman, 2009), as it pushes political organizations to create content that suits their target audience's ideas, than to inform them, in order to remain competitive (Hamilton \& Kim, 2004).

\section{Youth Development in Politics}

Youth development has been one of the core agendas as defined by the Malaysian Youth Policy 2015. With the concept of Positive Youth Development (PYD), youth development combines two main ideas. One perspective as described by Phelps \& Gestdottir (2011) is that the development of youth focuses on cognitive, emotion, social, and behavioral changes. This is in line with the second perspective by Benson, Skala, Hamilton, and Sesma (2006) where they posit that exposing youths to their surroundings will strengthen development as well. This means that youth leadership development requires participative learning and role models that can be emulated, an example that youths can follow (Lerne, Brittian \& Fay, 2007; Franklin \& Nahari, 2018). The second perspective is that their well-being will be improved when their strengths are compatible with appropriate behavioral reactions 
to their surroundings (Benson et al., 2006). Lerner, Li, Valdesolo, \& Kassam (2015) coined five core outcomes associated with youth development referred to as the $5 C^{\prime}$ s, which are competence, confidence, character, connection, and caring. These may be the criteria in which a youth can be considered to be successfully developed.

The struggle to develop youths, particularly in politics, is fragmented to give way to other priorities such as equipping youths with skills for employment and youth mental health. The lack of literature focused specifically on political development further reinforces that political development garners lower level priority compared to previously stated youth needs (Okolie \& Ajih, 2008). Youth development carries the process of preparing people to meet challenges through a dedicated, coordinated, and progressive program that is supported by experience to help them achieve the competencies. Thus, in politics, youths may need extensive guidance and mentoring before taking up the mantle of a politician. There is an indepth look into youth developments in Russian and Ukraine, which proposed that youth development has taken a positive turn in the 2000s (Topolova, 2006). Topolova noted that very little attention was paid to the youths, who were socially marginalized, ideologically disillusioned, and politically disenfranchised (Shevchuk \& Holobutsky, 2001). This led to a movement called the Orange Revolution that spurred a massive movement for youths to change political fundamentals in Ukraine. The Orange Revolution was on all counts, a display of the competencies proposed by (Edelman et al., 2004). The youths were ready for political change on a national scale, and to be inducted into the political field as equals to the traditional institutions that govern it.

However, apathy is still a considerable problem among youths in their socio-economic and political roles that still need to be addressed (Ahmad, \& Sheikh, 2020). Various tests have been done to see how apathy acts in social situations, empirical evidence such as negative experiences characterized by disengagement, disruption of attention, and perceived challenges based on activities were observed (Della Fave, \& Massimini, 2005). They proposed that structured activities arranged in a long-term schedule were necessary to dispel apathy. Nevertheless, this cannot be used to describe the entirety of the youth demographic, as the youths have varied levels of political interest. Some feel that hopeless in the face of current political climates, some do not believe that everyday politics affect them on any significant level, and some feel encouraged that they might have the power to make key changes in the political system and have not withdrawn their efforts (Ahmad, 2015).

\section{Political Participation with Youths}

Tom, Lynch, and al-Khatib (2019) have highlighted that youth political activists are distrusting of already established political agents such as the opposition parties, syndicates, and even the non-government organizations that try to recruit them to champion their politics. In Malaysia, where Muslims take up $60 \%$ of the population, Muslim youths are apathetic to politics (Institute of Ethnic Studies, 2012). However, they believe in the idea of checking and balancing democracy in the form of having strong opposition. Youth leadership has always been entrained in community development (Arshad \& Hong, 2019). Leadership is about influence, a leader must have followers where the process of influencing can be done (Samah, Jusoff, \& Silong, 2009). From this, a leader must be the pillar of a group that decides on the next actions taken by them. A leader is responsible for deciding on a direction that will be strategically beneficial for the group they are leading. In short, the most important 
elements that are within the leadership context are influence, followers, and goals (Northouse, 2019; Hughes, Ginnet \& Curphy, 2015). There are a few schools of thought to what constitutes leadership, which are summarized into ideas such as traits theory, behavioral theories, situational theories, and integrative theories. Northouse (2017) concluded that major leadership traits are typically centralized to intelligence, selfconfidence, determination, integrity, and sociability. Fiedler (1967) created the contingency theory which focuses on three dimensions, the leader-member relationship, task structure, and the leader's position of power. The theory basically explains that a leader's effectiveness is based on the situation. From this theory, therefore, Mohamad, Silong \& Hassan (2009) notes that leaders in Malaysia need to take into consideration the background of followers, due to the multiracial aspects, before applying their strategies.

Findings from research indicate that a lot of political engagement for youths is done informally in the 21st century. Youths gather and discuss through informal channels, most notably the internet, about political and national issues (Dekker, 2004). The importance of new media has developed into a communication necessity and directly contributed to the growth of political engagements in Malaysia. Such informal channels consist of bloggers and commentators that are two-way communication channels, with fewer censors as compared to traditional, mainstream media and forums organized by formal organizations (Nga, Liao, Hsu \& King, 2009). It is further postulated that informal new media are beginning to replace formal organizations for political engagements. The growing population of youths who are also potential voters is actively involved in cyber activities, making them a new political force. This culminates in significant crowds such as the BERSIH rally that is built up from online engagements (Channel News Asia, 2013).

The dynamism of engaging in youth politics focuses on the individualism that youths place in. Identity politics is a stance that has shaped the recent political landscape, with youths having the highest investment through engagements of diversity and breaking cultural boundaries (Sloam, 2007). However, Sloam also notes that the youths have lost interest in conventional politics, the youths are disenchanted by what they have observed in how traditional politicians operate to serve their own agendas (Park, 2005). Many youth engagements are increasingly done outside the systems of political gatherings and forums, with youths experiencing frustrations in core institutions that fall under governmental umbrellas (Mulgan \& Wilkinson, 1992). Another element that fuels this youth exit from political playing fields is that the political institutions themselves deny youths from taking on a more significant role in politics. This culture of non-participation has not given youths many opportunities to weigh in on political issues at a national level, which is a problem for political institutions as the youth demographic takes over a large portion of the populace (Matthews, Limb \& Taylor, 1988). In his arguments on youths and political engagements, O'Toole posits that political apathy and participation is a smaller problem compared to the bigger problem of trying to understand the concerns and issues that plague youths today (O'Toole, Lister, Marsh, Jones, \& McDonagh, 2003). Within the political process, some youths do not vote because they do not feel represented by politicians and political parties. This would alienate youths from pursuing politics as a relevant part of their lives, thereby denying the political playing field a demographic with huge potential (Marsh, O'Toole \& Jones, 2006). Hence, youths seek social media to charge their political voices instead of trusting long-established political institutions. As each new generation comes of age, it is also a test of engagement for 
the political institutions where their legitimacy is called into question if their practices do not serve the new generations.

\section{Current Political Environment for Malaysian Youths}

A paper written about the patriotism of youths in Malaysia described that the multiethnic understanding that Malaysia was formed on help drive in the core patriotic values among youth. These values are found in studies day in moral textbooks and civic programs in educational institutions to inculcate the idea of Malaysian patriotism into youths (Rahman, Ahmad \& Awang, 2019). However, this paper does not define the roles that the youth play within politics, only highlighting that multi-ethnic patriotism was an unbreakable state of mind in youths. Patriotism can be broken down into two perspectives: blind patriotism and constructive patriotism. The perspective of blind patriotism is a state of non-critical support towards a particular group. Constructive patriotism is an awareness of loyalty towards a group, more importantly, it is an understanding of one's role and responsibilities towards that group or what purpose one serves (Schatz, Staub, \& Lavine, 1999). Rahman, Ahmad, and Awang argue that this line between blind and constructive patriotism that has been clearly defined by Schatz has been blurred by the advent of social media. Thus, being an obstacle to the development of youths as future leaders of the country. Simply put, the youths are not eager to play the ball within politics.

However, other papers suggest differently, the researchers suggest that the sensibilities of the youth towards politics have developed as they understand their roles as actors and mediators, thus engaging in actions that allow them to have real dialogue in politics. Studies point out their significance in various Asian countries, including Malaysia, on how students of the arts and humanities engage in public duty and social projects in an effort to make a change in their environments (Cheng \& Jacobs, 2019). Another important exercise that the youths are undertaking in modern times is the rejection of existing ideals of how to be a citizen and the current political institutions that define it as well. In a more liberal environment as compared to the previous centuries, the youths have taken to themselves to create and articulate alternative roles that might fit new definitions of who they are as citizens, which is beyond the traditional boundaries established in politics (Zahan, 2020; Landgraf, 2020). Up until the 2018 Malaysian General election, Barisan Nasional did not field many youth leaders below the age of 40 . The party's most prominent leaders were Khairy Jamaluddin (UMNO, Chong Sin Woon (MCA), and Sivarraajh Chandran (MIC). Besides these notable youth leaders, other leaders fielded by Barisan were aged 50 and above. Though Khairy, being the most prominent youth leader from the coalition and having support from both sides of politics, the coalition did not yield much support from the youth demographic. For Pakatan Harapan however, fielded a significant number of younger candidates that were between their 30 s to mid-late $40 \mathrm{~s}$, all of whom champion ideals of anti-corruption and improving the economy. This resulted in Pakatan Harapan swaying much of the youth votes in the General Election (Waikar, 2020).

Arguments have been made regarding the apathy of the youths in South East Asian countries (Kimberlee, 2002; Pirie \& Worcester, 2000). The debate of the youths' perception towards politics is split into two sides in scholarly circles; the first group believes that the youths are disengaged or disinterested in politics, the second group believes that the youths have always been interested but engage in un conventional ways to show their political views through activities such as boycotts, strikes or protests (Henn \& Foard, 2014; Sloam \& Henn, 
2019). Though in different studies, Malaysian youths play an active part based on factors such as political vote, awareness, and the balance between benefit and cost of their votes. The benefits and costs of casting their votes play an important part in how youths perceive candidates or parties. This demographic needs to be able to see tangible consequences of what their vote has achieved, otherwise, political parties would not be able to get their confidence when it comes to elections (Esa \& Hashim, 2017). Awareness is also one of the main factors that dictate youths' political votes. Accessibility to information during an election period increases the likelihood of youths coming out to vote (Ghazali, Mohamed, Nasir \& Manan, 2019).

\section{Dilemmas of Youths in Politics}

In the Malaysian Youth Index 2015, studies were conducted through a survey with more than 6,098 respondents to measure the level of holistic development of youths. The holistic development is defined through 12 domains, each domain with 58 indicators that measure the level of holistic living experienced by the youth. With an index score of 45.82 out of 100 , political activism and awareness scored the lowest out of the 12 domains. According to the report, the significance of this number means that the youths are politically passive and are not informed on political issues on a national level. The study concludes that this area requires the most focus in the development of the youth in the coming years (Ministry of Youth and Sports, Indeks Belia Malaysia 2015, Mengukur Kesejahteraan Hidup Belia Malaysia 2015). But contrast to the 2015 Malaysian Youth Index, the youths of Malaysia organized a Digital Parliament that lasted for two days in June 2020. The objective of the Digital Parliament was to foster debate and discussion among the youths, on timely national issues such as education and technology (Kaur, 2020). At the same time, it was conducted to provide an example to the politicians that an online parliamentary session is possible and necessary. After months of inactivity in the Malaysian Parliament, numerous issues have cropped up nationally, from the current measures to curb the Covid-19 pandemic, to the issue of connectivity experienced by students in East Malaysia (Lee, 2020).

The evidence of youth enthusiasm for politics was made apparent in this digital forum, which showed the youths' abilities in highlighting issues succinctly while providing possible solutions to these issues. However, there has not been a response from the official parliament or individual politicians on the concept of a virtual parliament. Instead, the organizers and participants alleged to have been contacted by the police inquiring on details of the event (Augustin, 2020). This shows a part of the dilemma that youths suffer in politics, which is the lack of serious consideration by authorities. The digital parliament served as an important platform in which youths are allowed to share their perspective on national issues in a formal environment and to be taken seriously. Youth voices in politics are often dismissed by the adults in charge because of threats to the power of adults and the tendency to avoid glaring issues (Cook-Sather, 2006: Mithra, 2009). However, the youth voice is hard to do well, as it is a demographic that requires training and support to be able to contribute to political discourse (O' Donoghue, Kirshner, \& McLaughlin, 2002; Libby, Rosen, \& Sedonaen, 2005). The action of making youth voices heard in the political domain is also susceptible to threats such as the dominance of certain voices (Silva, 2001), simplification students' perspectives into a general group (Rudduck, 2007), and tokenistic messages in which people ignore (Filer, Pollard $\&$ Thiessen, 2002). The youths' voice is not clear and easily manipulated by such threats, resulting in their messages being manipulated and twisted for a particular agenda. 


\section{Method}

The approach for this research will be a qualitative research method. This study will employ qualitative methods that provide us with an in-depth understanding, an exploratory study that seeks to give meaning to how youths perceive politics at their current position and why they respond as such. In this research, the goal is to log and understand how the youths perceive current politics in Malaysia. Specifically, the researcher aims to answer the following questions: 1 . What are the issues faced by youths in the current political environment? 2 . How can aspiring politicians communicate effectively with youths in this era? 3 . What are the dynamics of political communication in youth circles?

This research will begin from a population in the form of youths in Klang Valley. The individuals named in the list were obtained from public sources such as the websites of the component parties, listing current holders of positions within the parties. For this research, our sample will be drawn from youths from three different institutions for three focus groups to be conducted. A list of questions will be developed for these focus groups, in a semistructured format that will encourage discussions and exchange of opinions, which will be recorded and transcribed. The analysis will be based on Burnard's (1991) method of analysing interview transcripts based on thematic analysis. As per the requirements of this research, four focus groups were conducted with youths from different institutions and backgrounds. The focus groups focused on fulfilling and finding out thoughts and opinions from students and young people who are already out in the workforce, on topics relating to the three core objectives of the study: 1) Issues faced by the youths 2) Effectiveness of political communication for youths 3) The dynamics of political communication in youth circles. The study also lists the themes of discussions in this chapter to highlight the key issues that were discussed by the respondents. The following steps are emulated according to Burnard's (1991) method of analysing focus group transcripts in qualitative research. The proposed method of analysis is on thematic analysis that has been recorded in full and has been transcribed.

\section{Results and Discussion}

\section{The Barriers of Entry for Youths in Politics}

When asked if youths have an easy time participating in politics, a majority (90\%) of the respondents showed slight amusement at the question. Marginalization is a common theme across youth politics, in Latin America, this is a common occurrence and studies have found that youths have been pessimistic about the future of politics especially when it is dictated by class and socioeconomic status (Galambos \& Loreta Martinez, 2007). Youths have been historically marginalized in the past due to their weak position in society, the current generation of youths looks to experience similar frustrations when discussing the level of entry into politics as one student (UM2) puts it bluntly:

"No for sure, the first thing is the barrier of entry which is age. Examples of youth politicians in parliament such as syed Saddiq are laughed at while the older politicians give useless speeches."

The other focus group participants from the same as well as different focus groups seem to resonate with what is being said here. However, one student from the same focus group (UM1), also said: 
"While it is somewhat difficult, official channels are not the only ways for youths to engage in politics"

When clarifying further, UM1 says that official channels are via television and radio broadcasts as well as newspapers. He says that social media like Twitter and Facebook are giving us a great platform and these platforms are increasing the youth's influence in the political field.

"Yes, even though it is simple, social media like Twitter and Facebook are giving us a great platform to discuss political issues."

UM3 proceeds to talk about how the pandemic has increased activity in Zoom and Google meet, which have provided a platform for activists such as Undi18 to hold events such as The Digital Parliament where youths can debate and share ideas about national issues These are forms of students demanding for reforms via the platforms available to them (Tunnerman, 1998). They use whatever platforms they can to start calls for democratization and modernization of national politics, one of the focuses remaining for better education (Liebman, 1972), which have remained unchanged over time and remain an issue today. Digital communication technologies represent a rapidly changing online ecosystem from which youths primarily build their cultures (Martin-Barbero, 2002), this makes today's youths one of the fast-changing and adapting generations in Malaysian politics.

"I saw recently Zoom and Google Meet are very good tools also to start a discussion that can be live-streamed. At least we can still get together and talk even though these pandemic cases are rising"

This sentiment is echoed by others in the focus group as well. See the advent of digital media has provided the tech-savvy generation of youths with various ways of engagement. However, one interesting answer from TARUC2 talked about race being a point to consider for youths entering politics, which implies that race is still a major factor for youths in politics:

"It is easy depending on race because we are considered the majority in Malaysia. So, if we want to join, we can. Just a matter of finding out who is suitable"

However, for some students such as TARUC3, it is very easy for them to participate because they have been involved with student political activities for a long time. This helps them establish a presence already among their peers It is note worth that students find it easier to participate in politics at an early stage if they are exposed early to politics:

"I am very aggressive in student politics, I participated in student politicism actively and I can say that it is easy for me."

The focus groups' thoughts on Malaysian politics at the moment remain quite pessimistic overall as they highlighted their troubles from the perspective of youths.

"Societal rules that tell us young people are not experienced enough for politics because they have not experienced enough of life. The fact is that we are going to be the future 
generation and the world is changing, we are changing with it. So, we have every right to be in politics.

UM2 highlighted this issue in politics where certain demographics do not get enough respect. This has been a prevalent issue in Malaysian politics. UM1 further reinforces this by saying that Malaysia has a traditional society where people still do not have enough trust towards younger individuals because they are less experienced. However, UM4 states that youths have more creativity and are more progressive when it comes to ideas about our politics.

"There are for sure barriers that prevent us from fully participating in politics. We are a traditional society, people don't trust younger individuals who are considered less experienced.

"But we are more creative and more progressive in our ideas, this is definitely for sure."

The other focus groups echo mostly the same sentiment, youths having a problem or severe difficulty when entering politics. UN1 from FG2 talks about the "old" politicians, who are conservative and not progressive, this is reinforced by UN4 where she says even though the older politicians carry more experience, they do not have a good perspective on what makes a country move forward.

"Even though the older politicians are experienced. They do not have a good perspective on the development of the country."

Some respondents are accepting of the current political situation in Malaysia, citing how the government is handling the pandemic as acceptable and that they are satisfied with the current governance (UN3, UUM1).

"I feel fine with the current situation. The government is trying its best and I would say we are well protected against the pandemic"

"I think looking at the situation in countries such as the United States, we have it good already. We have lots of stimulus packages and protection in terms of medicine and treatment. So, I am okay with how things are now."

However, UUM3, UN1, UUM2 highlights that there are problems but overall, she is fine with the way things are going. This is further reinforced by participants from other focus groups, who have highlighted problems such as economy and racism in the responses to the question.

"I am actually ok as well. Racial tensions are there but there are no racial riots. Our leaders are not the best but they are trying to keep the country stable."

"I feel that the current situation needs improvement. We need to see some progress in terms of development and not just reactive actions taken by our politicians." 
"It is not good enough, we are always trying to push for more representation for youths and students from our own society but it seems like nobody is listening" satisfied."

"There is a lot of room for improvement, overall, as a youth and a citizen, I am not

The theme of this particular section shows that students think the political environment is currently not welcoming to the youths. The current system, in their opinion, is that people are not warm to the idea of having youths represent them due to their perceived inexperience. The fact that Malaysia's population is an aging population shows that people might not be open to accepting a new generation of younger leaders. This has disenchanted youths from communicating more freely on the political playing field, where they once strived to engage in democratic activities, such as speaking openly and participating in protests and engaging others in discussions or debates (Munroe, 2002).

\section{Education and Knowledge of Youths in Politics}

The focus group then focuses on the view of education and its influence on politics in Malaysia, the questions revolve around extracting opinions of the respondents towards how education factors into politics in Malaysia. The simple question of it is whether education is vital or not to the development of youth in politics. From their responses, $60 \%$ or 9 out of 16 of the respondents believed in the usefulness and applications of education in politics. The focus group started this line of questioning off by querying how has the respondents' education affected their perception and judgment of youths and politics. Some have responded positively, such as UM1, who believes that a good education leads to better:

"Education for sure helps, more than what we study for our degrees, it helps us with critical thinking. And speaking as a student, I believe critical thinking is the most important thing we can learn from our education and this helps us be critical of our politics" UM4 reinforces this belief by making the following statement:

"I agree with Kenneth, education goes a long way for youths. We are educated about the news of the world. We know what's happening and when we keep updating ourselves with information, we are able to make informed opinions about issues."

This sentiment is echoed throughout other focus groups as well, as TARUC1 talks along the same line of reasoning regarding education:

"Education lets us be more critical in our thinking, it trains us to question things and learn things differently. So, I would say education has an impact on what we do."

The importance of education has long since been debated as to whether it is able to improve our understanding of the world. A person educated in communications may not necessarily have the same understanding of the world as someone with a degree in mathematics. And while both may have degrees, their opinions remain relevant only in their respective field of study. There is currently not enough literature to explore how different disciplines affect the perception of life differently. Overall, the first focus group reached a 
general consensus that education is helpful for helping youths fill in the gaps about their perception of politics.

However, the other focus groups had a similar theme throughout their discussions, which highlighted their opinions that education is not so useful when dealing with politics. UM2 is pessimistic about education, as he states:

"I feel education can only help us so much, while I agree with Kenneth, I think it is our attitudes that shape how we move forward in the world. This is what education can teach us."

Similarly, UN1, UN2, UUM3, and TARUC 3, from FG2 states reinforces the idea as well, by stating:

"Education is not so important; it is all about our own perception and how we gather information to form opinions."

"I find education slightly useless in terms of knowing about politics. I agree we should discuss with other people and read the news. But education is only a small part of understanding politics."

"We must be able to form our own judgement based on the information and what we talk about with other people."

"We have no education about politics at all, and basic education or even college education has no effect on our politics I think."

This also shows a possible hypothesis that youths learn more about the world when they graduate from school, which leads to them picking up and learning more life experiences as they enter the workforce. One can also say that the real-life challenges presented by entering the workforce are more relevant than the challenges they were presented as students. There is also a repeated theme of critical thinking, which is valued very highly by a majority of the respondents.

When questioned on the way they are learning about politics, the answers provided are very surface and elementary, citing news sources and social media as a primary source of information on politics. However, there is one interesting response from TARUC4 from FG4, which talks about how he adheres to his family's beliefs about politics.

"I listen a lot from my father and my uncle. We always like to talk about politics together. But every time, I only listen and do not comment. Because the adults don't really agree with the opinions of youths."

"I listen to my elders, and at the same time, I will give people a chance to discuss and debate with me as well."

However, here are some main themes from the majority of answers that share similarities between each other on the sources of news they access, this gives an idea of how the youths consume and access political information. 
"I usually read the news and discuss with other people, then form my own judgment. It is always good to make your own opinion."

"I read the news as well but I also follow social media of politicians to get the source."

"From news only, I found the information from a Facebook group that has a lot of Chinese in it. Sometimes it is really biased."

These are some of the common answers belonging to the theme, which can be classified as official sources of information. A few would be involved in discussions and debates, but not to a very in-depth level as they do not focus on that kind of political engagement. Though only one respondent from FG4 highlighted that he learns about politics through his activism in politics as well.

"As I mentioned during my university time, I participated in student activism and I involved myself in politics so I gained a lot of knowledge from there."

While some obtain sources of information from official channels, some rely on people via discussions, debates, or trust their family members completely. An important thing to note is that youths are open to having discussions with people, and are willing to accept opinions from other people. From the focus groups conducted, it seems that they are open and ready to be upfront about politics as a point of discussion.

Furthering from questioning how has education affected their own views of politics, the respondents were then asked if education plays an important part in politics? This is to find out how significant a part does education play in the eyes of the youths. There are arguments towards the usefulness of education in equipping youths with relevant skills to handle politics. Some would argue that politics is learned through experience and information gathered as a person experiences life, others would argue that education provides a more indepth look into politics because of its academic nature. Several people in the focus groups emphasize that education is simply limited and that it will not overly beneficial for youths in politics. For example, this response by UM3:

"Education plays a small part of a very complicated system. Politics requires life experiences, a perspective on how people are living and the ability to understand and empathize with the people's problems"

Additionally, UUM4 from FG2 commented on education only a component, needing more from our own understanding of the nation and its politics to compliment it:

"I think it is a mix, as we mentioned, it is our duty to learn more ourselves and understand our world. It is not just the duty of our teachers to pass on the knowledge to us."

This is further reinforced by comments from other respondents:

"I learned very little from school, mostly from news and such so I would say education does not mean a lot when it comes to politics" 
Most respondents concur that the learning must be done by the youths themselves instead of relying on education institutions, they echo the sentiment that learning is very much an independent process that is totally reliant on the youths being active. However, some feel that university is a good place to encourage students to be active and this is where passion for politics can be cultivated:

"University is always a good place to get students active and involved. It is where we start learning about the world and our country.

"We learn about our history in secondary school and this gives us a good foundation to understanding our country's roots."

Overall, the split between the usefulness of education for youths in politics is very split among the focus groups. But when asked about the relevance of a degree that is similar to the politics that youths are interested in, the responses are one-sided and seem to indicate that specific degrees are not necessary to comment or follow a particular branch of politics, such as this comment from TARUC3 in FG4:

"Absolutely not, you see our ministers that they don't have any qualifications in their respective ministry. We only had Yeo Bee Yin as an example who has her degree in science. The rest does not have relevant qualifications"

This is further reinforced by TARUC1's input:

"I think ministers do not need any degrees at all. They have set the bar so that we don't need any qualifications as well to join politics, so the youths are entitled to participate if they want to"

This shows the jaded perception of youths when discussing the qualifications of being a minister. With recent news on the qualifications of a few ministers in Malaysia, the competency has come into question nationwide about what it truly takes to participate in politics.

At the same time, many respondents commented that it is the right of the people to comment on the current state of the country, whether they are qualified or not.

"No, we don't need a degree to care about politics and make comments about it."

"It helps to know something more deeply, but politics is about the people, and we are the people."

"Education is good, but everyone agrees that we have a right to comment on our politics no matter who we are"

The theme revolving around the discussion about education is that the group remains unconvinced but positive that education plays an important role in youth politics somehow. Their ongoing concerns include the relevancy of what youths are taught today, which in the groups' opinion, does not equip them with knowledge about politics and its importance to 
the everyday life of Malaysians. The importance of politics is not communicated in the induction and education of youths as part of their critical thinking development. Examples of youths maturing and not subscribing to the importance of politics and how it affects our daily lives have not been prevalent in Malaysia. Politicians only choose to target specific groups to maximize their potential votes and the focus groups have pointed out that this is not the way to communicate with the youth demographic.

\section{The Current Abilities of Young Leaders}

In regards to the abilities of young politicians, their abilities also come into question for the youths. Underlining youth politics, youths make decisions as a collective, often referred to as protagonist citizens who perform direct actions that tackle organization, leadership, and decision making (Bonvillani, Palermo, Vázquez \& Vommaro, 2008). This is to observe how much trust the youths place in these leaders and their ability to lead and serve the people. As defined, a politician has to serve the people who elected them. Thus, 14 out of 16 or $80 \%$ of the respondents feel that it is good to evaluate them by their service towards the people. When asked about the awareness of the young politicians and activists towards our country's national issues. There is a hesitation and consideration to their responses before they answer, the responses that were given are also split as they highlighted the good and the bad as well. UM1 highlights the positives:

"I would say they are aware enough because these people are constantly learning and discussing various platforms available to use today. It is a great thing to see so much discussion among young people being opened up nowadays."

UM2 however, offered a more pessimistic view of the youth leaders:

"They are aware enough but still not much is done in terms of activity, debates are only half of what can be done for the country."

This implies that the youth leaders are not doing much for the country in the first place. The average youths see leaders as inept and inefficient when it comes to the use of resources and time, figuring that new and old leaders place less emphasis on good governance and representing the people, focusing instead of solidifying their position and winning the next election. This has been a long-time observation of political trends happening globally. However, the youths or new generation of politicians have sparked hope throughout the 2010s, inspiring a new kind of politics. However, much of it is unexplored in terms of how people think and how the youths perceive these new leaders. The new leaders, as the youths hope, embody a new politics that focuses on good governance and serving the people transparently. As UN3 from FG2 puts it:

"There is a certain way that a country should be governed, and that is based on our values and constitution. People need to respect the constitution as well."

UUM2 from FG3 is also adamant that more needs to be done before the youths can have the experience of older politicians when it comes to decision making and policy creation: 
"No, they are not ready. They still have a long way to go before being properly equipped to propose good policies. This is because older politicians are more experienced and have been through more problems and issues. They can handle things better."

Other respondents from the same focus group, UUM1 and UUM3 point out that for young leaders to do well, they must be given a chance to participate:

"How can they get experience if we don't give them a start? Leaders need to be trained and put through real-life first to be ready."

"Agreed, they need to have a start first. We must give them a chance to learn. This is called investing in the future."

In regards to the policies for youths, the tonality of the responses took a turn for the negative as the youths answered if they are satisfied with the direction of our youth policies. The overall gist of the responses can be summarized to say that there is not much being done for the development of youths at this time. Examples of such responses throughout the focus groups:

"I think we still have a long way to go before we settle on the right direction. There is not enough being done now for sure in terms of policies that focus on major youth development." (UUM4, FG3)

"Of course not, there are no policies for the real benefit of the youths." (UM2, FG1)

"Definitely not, I don't see youths being given a lot except the occasional book vouchers every now and then on top of the subsidies to studies. Certain demographics don't get as much either" (UN2, FG2)

"I don't think so, I don't think we have sufficient jobs and policies for the youths. Some jobs, we go out and work but the pay is not good even though we are professionals. We don't have enough jobs with enough pay for people like us." (TARUC3, FG4)

These are some of the responses which highlight the inadequacies of Malaysia's youth politics, when probed further, they detailed out jobs and salary as the number one source of their woes. On top of that, they are experiencing a lack of opportunities for jobs, noting that despite their professional qualifications, they are unable to work in the industry they have majored in.

Only one response out of the many responses talk about how things are going well (TARUC2, FG4):

"I think it is fair because I found a job even during Covid-19 after I graduate. Even the pay is not good but I appreciate I am given the opportunity. At the moment, we have a lot of job opportunities in Malaysia, Just the matter of whether you want to work or not." 
The question then proceeded to ask the respondents suggestions to improve communications with the youths to gain credibility. Credibility is gained from building trustable relationships with your stakeholders and following through with action. It is a result of how a person serves his or her community. The respondents were very clear with what they are looking for in terms of good communication with their representatives in politics. UM1 from FG1 emphasized being transparent and clear with your actions:

"Be very transparent and clear with your words and actions, you cannot say something to the people you represent and turn your backs on the community when it does not add to your advantage. This is very unrealistic by today's standards, but this is what it means to serve the people well."

The rest of the focus groups then silently agreed that politicians with their own agendas are bad for the country in the long run. This is also echoed across all the other respondents from different focus groups. Some provided suggestions such as UN1 from FG2:

"They must be on the ground more with the youths, tell us more and get to know us and our issues personally. I think politicians are out of touch because of their status and pay. They don't know what we care about, even the younger politicians."

UN2 from FG2 talks about focusing on our beliefs as youths as well:

"More than that, they are out of touch in terms of what we believe in as well. We believe in change, not keeping the status quo."

The theme observed for this particular topic is that the politicians should get to understand the youths as they are, what they value in society and this shows that they value progressive changes that allow everyone to rise and do more for the country. Riele (2006) highlighted the reasons why youths are at risk in a democratic society due to the issues of their demographic not being included in national policies. This has led to a disconnect between politicians and youths due to a lack of communication. The highlighted risks cover important issues such as education and marginalization as politicians fail to communicate with youths and therefore, have left youths in a dark place in the 21st century. Though youths may be savvy culturally and technologically, the world-building in terms of creating policies and understanding concepts of globalization are lacking from politicians, who have intentionally left these youths at risk from not being equipped well enough to handle the next generation.

\section{The Current State of Youth Politics}

On information, 14 out of 16 or $80 \%$ of respondents feel that the youths are not getting much information from the young leaders introduced in political parties. They are not presented with who these people are and what ideals they strive for besides towing the party line. As UM2 from FG1 puts:

"We are absolutely not getting enough information from them. If they want to do more for the country, they need to talk to everyone more. 
UM1 counters this idea, however, stating:

"A lot of examples such as Undi18 are doing just this though. I feel like this is a great period for youth politics where many activists are doing everything they can to inform us of change."

Though UM1 talks about his support for many activities being done to represent youths, the other respondents do not seem to echo his thoughts on the matter. Most would say claim that these youth leaders are just examples of tokenism simply used to disarm a demographic that is not a priority in the eyes of current political parties, such as this statement made by UN1 from FG2:

"Because they are not given enough space and freedom to execute their own ideas. They are just towing the party line and treating it as a form of tokenism."

This is a telling statement of how youths feel about the current political climate. Though there are representatives that champion national youth agendas, they are powerless in the face of their party goals and politicians with more authority. UN2 from FG2 respondent pointed out:

"We are not ready to embrace youth leaders because the population is not properly educated about the possibilities of having young leaders in parliament."

UN4 from the same focus group backed up the party logic by making this statement:

"Youth leaders get laughed off because they don't have enough backing from the parties they are supporting."

Besides the lack of political will being the issue, youths themselves do not understand enough of politics to throw their support behind the backs of new politicians as well, choosing to trust the politicians that are already established. This guarantees that the older politicians maintain their positions while young politicians are starved to prove themselves in the eyes of the public. Educating the youths on this issue seems to be a concern among the respondents such as UUM4 from FG3:

"We shouldn't just have courses in college for politics. I think younger students should be educated about the politics of the country from the past until today."

However, TARUC1 from FG4 feels differently about the youth's level of political knowledge:

"A lot of people are more aware and have a higher understanding of current issues now. We see more and more youths engaging but sad to still see the rural areas not being given more in terms of political awareness"

TARUC3 from the FG4 also agrees with this statement, adding:

"Yes, we have some programs that go into villages around Selangor to educate and understand the youths there. So far, their level of knowledge is very surface." 
The overarching theme is that the state of politics for the youths of Malaysia is still in its infancy and much more work needs to be done to be inclusive of youths and their ideas. Though the combination of societal barriers and age gaps are very difficult to bridge, youths are beginning to make their voices heard through many platforms and the few young politicians who are elected to parliament (Horsford, Scott \& Anderson, 2018). We see many thought leaders, who are not politicians, but educated individuals at the ground level who are surfacing up to give their opinions on important national matters. The focus groups feel that this should not be taken lightly as they have shown many examples of good political practice through their debates, discussions, and gatherings. The focus groups hope that one day, more youths will take part in politics not as careers but as actors of their own personal ideas on how to improve the country even further.

\section{Conclusion}

The focus groups seem to have pinpointed some problems regarding youths in politics. We see responses such as the lack of education and education as some of the reasons why youth politics is not prominent in this country, with $80 \%$ of the respondents voicing out concerns and disagreements against the current state of how education can benefit politics. However, the biggest takeaway from the focus groups is the barriers surrounding politics, which are age, experience, and general perception between old and new politicians. The older politicians have already established themselves with experience in governance and leadership, but are shown disdain when talking about their ideals which are not as progressive as the new politicians. The response towards new politicians shows that they are perceived as highly progressive, but are lacking the political will to prove themselves. Our part in society also makes a large difference as we lack vision as well when it comes to these new politicians as put by the respondents. We do not fully trust the new politicians yet, cautious of how they will change the nation and alter the status quo. Specific respondents pointed out that there are elements of classism and racism at play here, which favours one demographic over the other. However, most respondents pointed out that the young politicians are still weaker, unable to handle complicated national issues yet, but are willing to give them a chance.

Overall, the analysis of the results has highlighted key problems faced by young politicians and in extension, the youths in general. Education seems to be a recurring topic throughout various questions, showing that it is indeed one of the most important factors when it comes to political activism among youths. The youth political environment remains an undeveloped area in Malaysia. Many awareness and perception issues must be taken into consideration if we want to improve the standing of youths in this political environment. More communication exercises need to be done to bridge the gap between youths and the rest of the population. The effectiveness of education remains a debatable topic for the youths as the study has gathered testimonials on the nation's lackluster approach in regards to education. The emphasis placed inaccurately on the results can place mental stress on youths and may cause apathy towards any particular subject (Landgraf, 2020). Education is the first point in which youths interact with the world and begin to understand it. Thus, more focus should be placed on equipping youths with life skills that help them build an understanding of the world and its politics, only then can youths be more effective in actual environments such as parliaments, forums, and discussions with political officials. Education needs to be revamped in order to provide youths with more substantial weight on national matters. 
However, this is not the only problem as the study has spotted out that females generally do not have a significant share of voice in politics. Zahan (2020) pointed out the problem of gendered and sexualized ideas of politics in India, where young women are managed and controlled within patriarchal and paternalistic logics that deny women of their agency in politics. This has severely gutted women from participating in key decision-making processes in politics, which leads to apathy among young women towards politics as well. Ideas of politics are not limited to men, but women whose perspectives may be valuable in improving politics for the youths.

\section{Implication}

Youths in general are disenfranchised by the current state of politics. This is why more focus needs to be placed in communicating with the youths, a growing and maturing demographic, in finding out what issues they want resolved. This can be done best by putting forth the youth politicians and establishing a bridge between the aging political party and the youth demographic. Political parties need to recognise the advantage that youths have in communications, as they are incredibly savvy with technology and are widely exposed to many influences and topics due to the internet where cultures are converging. The focus groups highlight that politicians are selective with who they communicate and who they have representing the party, saying that they are too careful with displeasing one demographic while pleasing another. This is not true per some responses in the focus groups. Youths need a face that they can relate to, this means that putting up a person who is from their age group can directly set the party to be more in touch with the youths, as it presents that they can relate to the struggles of the youths. This will be a more effective way of conducting good communications with the youth demographic.

\section{References}

Ahmad, D. K., \& Sheikh, D. K. S. (2020). Social media and youth participatory politics: A study of university students. South Asian Studies, 28(2).

Ahmad, S. (2015). Role of socioeconomic status and political participation in construction of apathy among youth. Journal of Human Behavior in the Social Environment, 25(8), 801809.

Arshad, M. M., \& Hong, T. H. (2019). Police Leadership in Developing Youth Leaders in The Community: Positive Youth Development Perspectives in Malaysia. International Journal of Academic Research in Business and Social Sciences, 9(11).

Augustin, S. (2020). IGP says in the dark over questioning on virtual Parliament.

Bennett, S. E. (1997). Why Young Americans Hate Politics, and What We Should Do about It1. PS: Political Science \& Politics, 30(1), 47-53.

Benson, P. L., Scales, P. C., Hamilton, S. F., \& Sesma, A. J. (2006). Positive youth development: Theory, research, and applications. In R. M. Lerner (Ed.), Theoretical models of human development. Volume 1 of Handbook of Child Psychology (6th ed.) (pp. 894-941). Editors-in-chief: W. Damon \& R. M. Lerner. Hoboken, NJ: Wiley.

Blekesaune, A., Elvestad, E., \& Aalberg, T. (2012). Tuning out the world of news and current affairs-An empirical study of Europe's disconnected citizens. European Sociological Review, 28(1), 110-126.

Blumler, J. G. (2016). The fourth age of political communication. Politiques de communication, (1), 19-30. 
Bonvillani, A., Palermo, A. I., Vázquez, M., \& Vommaro, P. A. (2008). Juventud y política en la Argentina (1968-2008). Hacia la construcción de un estado del arte. Revista argentina de sociología, 6(11), 44-73.

Boyman, S. N. (2017). Students and Campus Elections: Case study at Sultan Idris Education University, Malaysia. International Journal of Humanities and Social Sciences, 9(6), 3245.

Burnard, P. (1991). A method of analysing interview transcripts in qualitative research. Nurse education today, 11(6), 461-466.

Cammaerts, B., Bruter, M., Banaji, S., Harrison, S., \& Anstead, N. (2014). The myth of youth apathy: Young Europeans' critical attitudes toward democratic life. American Behavioral Scientist, 58(5), 645-664.

Channel News Asia. (2013). Young voters as kingmakers?15April[online]. [Accessed 11July2013] Available from World Wide

Web:http://www.channelnewsasia.com/news/specialreports/malaysiadecides/news/ young-voters-as/639356.html

Cook-Sather, A. (2006). Sound, presence, and power: "Student voice" in educational research and reform. Curriculum inquiry, 36(4), 359-390.

Dean, D., \& Croft, R. (2001). Friends and relations: long-term approaches to political campaigning. European Journal of Marketing.

Dekker, P. (2004). Social capital of individuals. Investigating Social Capital Comparative Perspectives on Civil Society, Participation and Governance, New Delhi: Sage Publications, 88-110.

Delle Fave, A., \& Massimini, F. (2005). The investigation of optimal experience and apathy: Developmental and psychosocial implications. European psychologist, 10(4), 264-274.

Earl, J., \& Beyer, J. L. (2014). The dynamics of backlash online: Anonymous and the battle for WikiLeaks. In Intersectionality and social change. Emerald Group Publishing Limited.

Edelman, A., Gill, P., Comerford, K., Larson, M., \& Hare, R. (2004). Youth Development \& Youth Leadership. A Background Paper. Institute for Educational Leadership.

Ekman, J., \& Amnå, E. (2012). Political participation and civic engagement: Towards a new typology. Human affairs, 22(3), 283-300.

Elishev, S. O. (2010). Theoretical and methodological approaches to the study of the concepts of «value» and «value orientations».[Vestnik moskovskogo universiteta]. Sociology and Political Science, 3, 74-90.

Esa, N. B., \& Hashim, R. B. (2017). Journal of Political Sciences \& Public Affairs.

Etgar, R., \& Tamir, E. (2020). Are millennial students better equipped to overcome choice bias? International Journal of Adolescence and Youth, 25(1), 373-381.

Fiedler, F. E. (1967). A Theory of Leadership Effectiveness. Mcgraw-Hill Series In Management. Filatova, O., Golubev, V., \& Ulianovskii, A. (2016). Young people's values: Identifying trends in Russian e-society. In Proceedings of the International Conference on Electronic Governance and Open Society: Challenges in Eurasia (pp. 143-148).

Filer, A., Pollard, A., \& Thiessen, D. (Eds.). (2002). Children and their curriculum: The perspectives of primary and elementary school children. Routledge.

Franklin, U. E., \& Nahari, A. A. (2018). The Impact of e-learning on academic performance: preliminary examination of King Khalid University. DEVELOPMENT, 7(1).

Galambos, N. L., \& Martínez, M. L. (2007). Poised for emerging adulthood in Latin America: A pleasure for the privileged. Child Development Perspectives, 1(2), 109-114. 
Galston, W. A., \& Galston, W. A. (2002). Liberal pluralism: The implications of value pluralism for political theory and practice. Cambridge University Press.

Gerodimos, R. (2010). New media, new citizens: the terms and conditions of online youth civic engagement (Doctoral dissertation, Bournemouth University).

Ghazali, W. N. W. M., Mohamed, S., Nasir, N. S. M., \& Manan, K. A. (2019). Personalised Campaigns in Party-Centred Politics: Facebook and Instagram as Arena for Political Communication. lium Journal of Human Sciences, 1(2), 52-64.

Hamilton, N., \& Kim, S. (2004). Democratization, economic liberalization, and labor politics: Mexico and Korea. Comparative Sociology, 3(1), 67-91.

Han, R., \& Xu, J. (2020). A comparative study of the role of interpersonal communication, traditional media and social media in pro-environmental behavior: A China-based study. International journal of environmental research and public health, 17(6), 1883.

Henn, M., \& Foard, N. (2014). Social differentiation in young people's political participation: the impact of social and educational factors on youth political engagement in Britain. Journal of Youth Studies, 17(3), 360-380.

Hindman, D. B. (2009). Mass media flow and differential distribution of politically disputed beliefs: the belief gap hypothesis. Journalism \& Mass Communication Quarterly, 86(4), 790-808.

Horsford, S. D., Scott, J. T., \& Anderson, G. L. (2018). The politics of education policy in an era of inequality: Possibilities for democratic schooling. Routledge.

Hughes, R. L., Ginnett, R. C., \& Curphy, G. J. (2015). Enhancing the Lessons of Experience Eighth Edition.

Kaur, K. (2020). Malaysian Youth Organise First-Ever Digital Parliament To Prove It Can Be Done. The Rakyat Post. https://www.therakyatpost.com/2020/06/22/malaysianyouth-organise-first-ever-digital-parliament-to-prove-it-can-be-done/

Kay, D., \& Hinds, R. (2012). A practical guide to mentoring: how to help others achieve their goals. Constable \& Robinson.

Keith, B. E., Magleby, D. B., Nelson, C. J., Orr, E. A., \& Westlye, M. C. (1992). The myth of the independent voter. Univ of California Press.

Kimberlee, R. H. (2002). Why don't British young people vote at general elections?. Journal of youth studies, 5(1), 85-98.

Kovach, B., \& Rosenstiel, T. (2007). What newspeople should know and the public should expect. The Elements of Journalism.

Landgraf, C. (2020). Politicizing youth in South Korea-the role of Seoul's educational institutions. Space and Polity, 24(1), 30-44.

Lasswell, H. D. (1948). The structure and function of communication in society. The communication of ideas, 37(1), 136-139.

Lee, S. (2020). Sabah student stays overnight in tree to get better Internet connection for online university exams. Retrieved July 09, 2020, from https://www.thestar.com.my/news/nation/2020/06/16/sabah-uni-student-staysovernight-in-tree-to-get-better-internet-connection-for-online-exams

Leong, P. P. Y. (2015). Political communication in Malaysia: A study on the use of new media in politics. JeDEM-eJournal of eDemocracy and Open Government, 7(1), 46-71.

Lerner, J. S., Li, Y., Valdesolo, P., \& Kassam, K. S. (2015). Emotion and decision making. Annual review of psychology, 66, 799-823.

Lerner, R. M., \& Busch-Rossnagel, N. A. (Eds.). (2013). Individuals as producers of their development: A life-span perspective. Elsevier. 
Lerner, R. M., Brittian, A. S., \& Fay, K. E. (2007). Mentoring: A Key Resource for Promoting Positive Youth Development. Research in Action. Issue 1. MENTOR.

Levin, J. (2007). Nontraditional students and community colleges: The conflict of justice and neoliberalism. Springer.

Libby, M., Rosen, M., \& Sedonaen, M. (2005). Building youth-adult partnerships for community change: Lessons from the youth leadership institute. Journal of Community Psychology, 33(1), 111-120.

Liebman, A., Walker, K. N., Walker, K. N., \& Glazer, M. (1972). Latin American university students: A six nation study. Harvard University Press.

Lippman, W. (1922). Public opinion. NY.

Mardani, M., \& Fallah, R. (2018). Comparison of Financial Leverage Ratio before and after the Use of Off-Balance Sheet Financing in Firms Listed in the Tehran Stock Exchange. Dutch Journal of Finance and Management, 2(2), 53.

Marsh, D., O'Toole, T., \& Jones, S. (2006). Young people and politics in the UK: Apathy or alienation?. Springer.

Martín-Barbero, J. (1996). Comunicación fin de siglo.¿ Para dónde va nuestra investigación?. Telos, 47, 58-64.

Matthews, H., Limb, M., \& Taylor, M. (1999). Young people's participation and representation in society. Geoforum, 30(2), 135-144.

Mazzoleni, G., \& Schulz, W. (1999). "Mediatization" of politics: A challenge for democracy?. Political communication, 16(3), 247-261.

McNair, B. (2017). An introduction to political communication. Taylor \& Francis.

Mitchell, A., Gottfried, J., Barthel, M., \& Shearer, E. (2016). The modern news consumer: News attitudes and practices in the digital era.

Mitra, D. L. (2009). Strengthening student voice initiatives in high schools: An examination of the supports needed for school-based youth-adult partnerships. Youth \& Society, 40(3), 311-335.

Mohamad, M., Silong, A. D., \& Hassan, Z. (2009). Participative and effective community leadership practice in Malaysia. Journal of Human Resource and Adult Learning, 1.

Mulgan, G., \& Wilkinson, H. (1992). The Enabling State. Real-Life Economics: Understanding Wealth Creation. London: Routledge, 340-352.

Munroe, T. (2002). An introduction to politics. Lectures for first-year students. Kingston.

Nelson, T. E., \& Kinder, D. R. (1996). Issue frames and group-centrism in American public opinion. The Journal of Politics, 58(4), 1055-1078.

Nelson, T. E., \& Oxley, Z. M. (1999). Issue framing effects on belief importance and opinion. The journal of politics, 61(4), 1040-1067.

Newman, B. I., \& Perloff, R. M. (2004). Political Marketing: Theory, Research, and Applications1. In Handbook of political communication research (pp. 35-62). Routledge.

Nga, J. L. H., Liao, L. M., Hsu, S. J., \& King, V. T. (2009). Internet, Youth and Democracy: Political Participation of Malaysian Youth.

Niemi, R. G., \& Jennings, M. K. (1991). Issues and inheritance in the formation of party identification. American Journal of Political Science, 970-988.

Nikitin, A. A., Nikitina, T. I., \& Filimonov, V. L. (2019). The role and place of youth political organizations in the formation of public opinion in the Republic of Tatarstan. International Journal of Engineering and Advanced Technology, 9(1), 74417443. 
Northouse, P. G. (2019). Introduction to leadership: Concepts and practice. SAGE Publications, Incorporated.

O' Donoghue, J. L., Kirshner, B., \& McLaughlin, M. (2002). Introduction: Moving youth participation forward. New directions for youth development, 2002(96), 15-26.

Onodera, H., Lefort, B., Maiche, K., \& Laine, S. (2020). Dynamics of engagement among youth in Arab Mediterranean countries. The Journal of North African Studies, 25(2), 280-303.

O'Toole, T., Marsh, D., \& Jones, S. (2003). Political literacy cuts both ways: The politics of nonparticipation among young people. The political quarterly, 74(3), 349-360.

Park, B. G. (2005). Spatially selective liberalization and graduated sovereignty: Politics of neoliberalism and "special economic zones" in South Korea. Political Geography, 24(7), 850873.

Pirie, M., \& Worcester, R. (2000). THE BIC, TURN-OFF.

Rahman, A. A. A., Ahmad, A. R., \& Awang, M. M. (2019, October). Patriotism Among MultiEthnic Youths in Malaysia. In The 2nd International Conference on Sustainable Development \& Multi-Ethnic Society (pp. 1-5). Redwhite Pres.

Riele, K. T. (2006). Youth 'at risk': further marginalizing the marginalized?. Journal of education policy, 21(2), 129-145.

Rudduck, J. (2007). Student voice, student engagement, and school reform. In International handbook of student experience in elementary and secondary school (pp. 587-610). Springer, Dordrecht.

Samah, S. A. A., Jusoff, K., \& Silong, A. D. (2009). Does Spoon-feeding Impede Independent Learning?. Canadian Social Science, 5(3), 82-90.

Samsi, A. H., Rahman, A. A., \& Samsu, K. H. K. (2013). Persepsi belia terhadap parti politik dan tahap penglibatan politik di Selangor. Malaysian Journal of Youth Studies, 9, 107.

Schatz, R. T., Staub, E., \& Lavine, H. (1999). On the varieties of national attachment: Blind versus constructive patriotism. Political psychology, 20(1), 151-174.

Schulz, W. (2014). Mediatization and new media. In Mediatization of politics (pp. 57-73). Palgrave Macmillan, London.

Shevchuk, O., \& Holobutsky, O. (2001). Information Society: to be or not to be. Atlas UMS, Kyiv.

Silva, E. (2001). 'Squeaky Wheels and Flat Tires': a case study of students as reform participants. In Forum, 43 (2), 95-99. Symposium Journals.

Sloam, J. (2007). Rebooting democracy: Youth participation in politics in the UK. Parliamentary affairs, 60(4), 548-567.

Sloam, J., \& Henn, M. (2019). Youthquake 2017: The rise of young cosmopolitans in Britain (p. 129). Springer Nature.

Stanyer, J. (2005). Political parties, the Internet and the 2005 general election: from web presence to e-campaigning?. Journal of Marketing Management, 21(9-10), 1049-1065.

Strömbäck, J., Djerf-Pierre, M., \& Shehata, A. (2013). The dynamics of political interest and news media consumption: A longitudinal perspective. International journal of public opinion research, 25(4), 414-435.

Theocharis, Y., \& Van Deth, J. W. (2018). The continuous expansion of citizen participation: a new taxonomy. European Political Science Review, 10(1), 139-163.

Thorson, K. (2014). Facing an uncertain reception: Young citizens and political interaction on Facebook. Information, Communication \& Society, 17(2), 203-216.

Topalova, V. (2006). In Search of Heroes: Cultural Politics and Political Mobilization of Youths in Contemporary Russia and Ukraine. Demokratizatsiya, 14(1). 
Tünnermann, C. (1998). Capítulo VI. Balance de la reforma a noventa años del Grito de Córdoba. Noventa años de la Reforma Universitaria de Córdoba: 1918-2008.

Van Aelst, P., Strömbäck, J., Aalberg, T., Esser, F., De Vreese, C., Matthes, J., ... \& Papathanassopoulos, S. (2017). Political communication in a high-choice media environment: a challenge for democracy? Annals of the International Communication Association, 41(1), 3-27.

Vowe, G., \& Henn, P. (2016). Leitmedium Fernsehen. Online im Internet unter: http://www. bpb. de/gesellschaft/medien-und-sport/medienpolitik/172063/leitmedium-fernsehen.

Waikar, P. (2020). Generational divide: how Pakatan Harapan swung the youth vote in GE14. The Round Table, 109(2), 155-172.

Xenos, M., Vromen, A., \& Loader, B. D. (2014). The great equalizer? Patterns of social media use and youth political engagement in three advanced democracies. Information, Communication \& Society, 17(2), 151-167.

Yom, S., Lynch, M., \& al-Khatib, W. (2019). Youth Politics in the Middle East and North Africa. Youth Politics in the Middle East and North Africa, 3-6.

Zahan, S. J. (2020). Feminist politicization of the urban: young female students challenging spatial patriarchies. Space and Polity. 